\title{
Antifungal Activity of Bacterial Strains from Maize Silks against Fusarium Verticillioides
}

Gisele de Fátima Dias Diniz

UFMG: Universidade Federal de Minas Gerais

\section{Luciano Viana Cota}

Embrapa: Empresa Brasileira de Pesquisa Agropecuaria

José Edson Fontes Figueiredo

Embrapa: Empresa Brasileira de Pesquisa Agropecuaria

Frederick Mendes Aguiar

Embrapa: Empresa Brasileira de Pesquisa Agropecuaria

Dagma Dionisia da Silva

Embrapa: Empresa Brasileira de Pesquisa Agropecuaria

Ubiraci Gomes de Paula Lana

Embrapa: Empresa Brasileira de Pesquisa Agropecuaria

Vera Lucia dos Santos

UFMG: Universidade Federal de Minas Gerais

Ivanildo Evodio Marriel

Embrapa: Empresa Brasileira de Pesquisa Agropecuaria

Christiane Abreu Paiva ( $\sim$ christiane.paiva@embrapa.br)

Embrapa: Empresa Brasileira de Pesquisa Agropecuaria https://orcid.org/0000-0002-1874-2489

\section{Research Article}

Keywords: antagonistic microorganisms, biocontrol, antimicrobials, phytopathogen, stalk rot, rot grain

Posted Date: July 1st, 2021

DOI: https://doi.org/10.21203/rs.3.rs-469163/v1

License: (c) (i) This work is licensed under a Creative Commons Attribution 4.0 International License. Read Full License 


\section{Abstract}

Fusarium verticillioides is pathogenic to maize and mycotoxin-producer, causing yield losses, feed and food contamination, and risks to human and animal health. Endophytic (ISD04 and IPR45) and epiphytic (CT02 and IM14) bacteria from maize silks were tested in vitro and greenhouse against $F$. verticillioides and for hydrolytic enzyme production (cellulase, pectinase, protease, lipase, and chitinase). The strains were assigned as Achromobacter xylosoxidans (ISD04), Pseudomonas aeruginosa (IPR45), and Bacillus velezensis (СT02 and IM14) by $16 \mathrm{~S}$ gene sequencing. All strains showed antifungal activity in vitro with inhibition values from 58.5-100\%; they changed hyphae morphology and inhibited the conidial germination by up to $100 \%$ (IPR45). The four strains produced at least one enzyme with antifungal activity. The microbiolized seeds reduced the fungal development in stored grains and stalk rot severity in the greenhouse by $72.6 \%$ (ISD 04). These results highlight the potential of these strains as biocontrol agents against $F$. verticillioides

\section{Introduction}

The fungus Fusarium verticillioides (Sacc.) is one of the major pathogens causing significant economic losses in the maize production globally (Jia 2019; Rosa Junior et al. 2019). The fungus can cause different disease symptoms in almost all plant parts, such as stalk and ear rot (Deepa and Sreenivasa 2017; Gai et al. 2018). Feed and food contaminated with toxic secondary metabolites as fumonisins produced by $F$. verticillioides are harmful to animal and human health (Deepa and Sreenivasa 2017; Blacutt et al. 2018; Zubrod et al. 2019). F. verticillioides is transmitted through the seeds, root lesions, wounds on the adult plant, or silks. The latter is the most critical contamination risk factor, leading to grain rupture, ear rot, and fumonisin accumulation in grains (Munkvold et al. 1997).

Synthetic fungicides are among the basic principles of plant disease management and have been used for decades worldwide to control plant pathogenic fungi (Yoon et al. 2013; Haq et al. 2020). However, their systematic and uncontrolled use has undesirable effects on non-target organisms, disrupted the ecological balance, and often led to fungal resistance (Yoon et al. 2013; Kim et al. 2017). Therefore, alternative procedures have been developed for crop protection. Intensive investigations on natural antagonists and their active metabolites with fungicide effects have been undertaken to reduce the use of hazard fungicides, and create new safe products for humans and the environment (Dukare et al. 2019; Jia 2019). The use of antagonistic bacteria for controlling plant pathogenic fungus represents a promising environmental safe and low-cost alternative to reducing synthetic fungicides in agriculture (Rahman et al. 2017). Biocontrol agents act against phytopathogens by different mechanisms, including the synthesis of antifungal metabolites and secretion of hydrolytic enzymes (Dukare et al. 2019). Lipopeptides and enzymes act on the fungal mycelial structure altering its shape, size, and surface and causing breakages (Borah et al. 2016). Enzymes also lead to weakening or degradation of the fungal cell wall and membranes, preventing their growth (Neeraja et al. 2010; Köhl et al. 2019). Different classes of hydrolytic enzymes produced by antagonistic bacteria represent an important mechanism directed against phytopathogens, useful for sustainable plant disease management (Jadhav et al. 2017). 
However, the mechanisms involved in the biological control are very complex and encompass competition, antibiosis, parasitism, induction of systemic acquired resistance (SAR), induction of systemic resistance (ISR), and soil suppressiveness (Jadhav et al. 2017; Hornby 1983; Rabbee et al. 2019).

Antifungal lipopeptides produced by Bacillus sp., such as iturin, fengycin, and surfactin, have a strong inhibitory effect against pathogenic fungus and harmful rhizosphere microorganisms (Ongena and Jacques 2008; Devi et al. 2019). Bacillus velezensis is a plant growth-promoting bacterium with various strains suppressing the growth of microbial pathogens (Rabbee et al. 2019). Genomic analysis showed that this species possesses strain-specific secondary metabolites gene clusters involved in the secondary metabolites synthesis, which play significant roles in pathogen suppression. Bioactive antimicrobial composts produced by $B$. velezensis have full applications in the pharmaceutical industry and medicine (Meena et al. 2019). B. velezensis also synthesize secondary metabolites that trigger induced systemic resistance in plants (Chen et al. 2018; Rabbee et al. 2019). Other beneficial metabolites include bacteriocins that inhibit the growth of similar or closely related bacterial strains, and secondary interkingdom interactions (antagonism, mutualism, intra- and interspecies regulation), and at-a-distance influence on bacterial behavior (Tilocca et al. 2020).

Achromobacter xylosoxidans is a plant growth-promoter, and produce the antifungal compost Cyclo (LLeucyl-L-Prolyl), a cyclic dipeptide that inhibits the growth of phytopathogenic fungi (Kumar et al. 2005; Vyas et al. 2018). A study by Dhaouadi et al. (2018) found that $A$. xylosoxidans reduced significantly $80 \%$ of the mycelial growth Fusarium in vitro. In the greenhouse conditions, the bacteria reduced considerably in $60 \%$ of the disease severity on melon plants inoculated with the pathogen. In another in vitro study, the strain AUM54 of A. xylosoxidans inhibited by $11 \%$ the mycelial growth of Magnaporthe oryzae, the causal agent of rice blast disease. In the greenhouse, plants originated from seed treated with the bacterial strain inoculated with the fungus showed a reduction of the disease incidence by $39 \%$ (Joe et al. 2012). The strain AUM54 also promotes seed germination, seedling vigor, and enhanced plant growth and yield. AUM54 moved systemically through the roots and stem of plants and significantly increase the activity of defense-related enzymes such as polyphenol oxidase (PPO), peroxidase (POD), phenylalanine ammonialyase (PAL), and chitinase (Vaidya et al. 2001; Joe et al. 2012; Veliz et al. 2017). Zhang et al. (2016) demonstrated that the culture filtrate of Achromobacter xylosoxidans strain 09X01 caused high mortality of the second-stage juvenile nematodes and reduced egg hatch in vitro. In the greenhouse and field trials, the treatments with bacterial suspensions of 09X01 significantly reduced the numbers of white females in roots. The strain 09X01 also increased the wheat yields by $13.2 \%$ compared to untreated control (Zhang et al. 2016).

Many strains of Pseudomonas sp. has been extensively utilized as a biocontrol agent and plant growth promoters (Manuel et al. 2011). These bacteria exhibit a broad spectrum of activity against a range of phytopathogenic fungi, producing lipopeptides, and proteases, essential for fungal control. Some strains produce phenazine-1-carboxylic acid, phenazine-1-carboxamide, and other exometabolites with antifungal activity (Shtark et al. 2003). The antibiotic 2,4-diacetylphloroglucinol (DAPG) is highly toxic to 
many plant pathogenic fungi and contributes to the biological control of plant disease. Pseudomonas species secrete fungal cell wall-degrading enzymes, such as glucanases, proteases and lipase (Poritsanos et al. 2006; Dharni et al. 2012; Chalotra et al. 2019). Hydrogen cyanide (HCN), a volatile secondary metabolite produced by $P$. aeruginosa, is recognized as a highly toxic antibiotic against plant pathogens. Siderophores synthesized by Pseudomonas sp. also exhibit antimicrobial activity (Keswani et al. 2020).

The isolation of antagonistic bacteria from their natural environment is crucial for the effectiveness of the biological control since they will be better adapted to survive and compete with other microorganisms adapted to the same environment (Figueroa-López et al. 2016; Blacutt et al. 2018). In this study, we tested four bacterial strains from maize silks for antifungal activity against $F$. verticillioides, the causal agent of the stalk and ear rot, and fumonisin producer.

\section{Material And Methods}

\section{Microbial strains}

The antifungal activity tests against $F$. verticillioides were performed with four bacterial strains from the maize silks from the Coleção de Microrganismos Multifuncionais e Fitopatogênicos of the Embrapa Milho e Sorgo, City of Sete Lagoas, Minas Gerais state, Brazil. The strains were collected in the localities of Sete Lagoas-MG, Sidrolândia-MS and Sertaneja-PR, in the year 2016. The Fusarium verticillioides isolate CML2743 used in the antagonism tests was from the Laboratório de Fitopatologia of the Embrapa Milho e Sorgo.

\section{Molecular identification of the bacterial strains}

The partial 16S rRNA gene sequence was used for identifying the four bacterial strains. Genomic DNA extraction was performed by the Wizard ${ }^{\circledR}$ Genomic DNA Purification kit (Promega, USA). PCR amplification of the $16 \mathrm{~S}$ rRNA was carried out with the bacterial universal primers $8 \mathrm{~F}\left(5^{\prime}-\right.$ AGAGTTTGATCCTGGCTCAG-3) and 1492R (5'-GGTTACCTTGTTACGACTT-3) designed by Turner et al. (1999). PCR reactions consisted of $20 \mathrm{ng}$ of bacterial genomic DNA plus $2.0 \mu \mathrm{L} 10 \mathrm{X}$ PCR buffer $(20 \mathrm{mM}$ Tris- $\mathrm{HCl} \mathrm{pH} \mathrm{8.4,50} \mathrm{mM} \mathrm{KCl}), 0.8 \mu \mathrm{L}$ of each primer $(10 \mu \mathrm{M}), 1.5 \mu \mathrm{L}$ dNTP $(2,5 \mathrm{mM}$ each), $0,6 \mu \mathrm{L}$ of $\mathrm{MgCl} 2$ $(50 \mathrm{mM}), 0,2 \mu \mathrm{L}$ of Taq DNA polymerase $(5 \mathrm{U} / \mu \mathrm{L})$ (Invitrogen, USA) and the total reaction volume adjusted to $20 \mu \mathrm{L}$ with ultrapure water. The PCR amplification was performed in a model Veriti ${ }^{\circledR} 96$-Well Thermal Cyclers (Applied Biosystems, EUA) with the following conditions: one step of 2 min at $95^{\circ} \mathrm{C}$ for DNA denaturation, followed by 30 cycles of $30 \mathrm{~s}$ at $94^{\circ} \mathrm{C}, 30 \mathrm{~s}$ at $59^{\circ} \mathrm{C}$ and $90 \mathrm{~s}$ at $72{ }^{\circ} \mathrm{C}$, and a final extension step at $72{ }^{\circ} \mathrm{C}$ for $10 \mathrm{~min}$. The PCR products were analyzed by $1.0 \%$ (wt/vol) agarose gel electrophoresis and documented using the Gel Logic 200 system (KODAK Company, USA). The nucleotide sequences were determined on both strains using the PCR primers in the ABI PRISM 3500xL Genetic Analyzer Sequencer (Applied Biosystem, USA). The sequences alignments were made with the Sequencher 4.1.4 program (Genes Codes Corporation), and the alignment research tool (BLAST) was used to find 
similarities with sequences in the NCBI database (http://www.ncbi.nlm.nih.gov/). The edited sequence of each species was deposited in the Gene Bank and received the following accession number: Bacillus velezensis strain CT02 (MK461847), Bacillus velezensis strain IM14 (MK461831) Pseudomonas aeruginosa (MK461572) and Achromobacter xylosoxidans (MK461853).

\section{In vitro antifungal activity against Fusarium verticillioides}

The antagonistic test was carried out by previously growing the four bacterial strains ISD04, IPR45, CT02, and IM14 and $F$. verticillioides CML2743 on potato dextrose agar (PDA) medium. After, a $5 \mathrm{~mm}$ diameter from actively growing fungus was transferred to the center of a new plate containing PDA medium, and $10 \mu \mathrm{L}$ of bacterial suspension $\left(10^{8} \mathrm{UFC} / \mathrm{mL}\right)$ was applied in four equidistant points, near the periphery of the culture. The plates were incubated at $28^{\circ} \mathrm{C}$ under the $12 \mathrm{~h}$ photoperiod for seven days. The antifungal activity was estimated by measuring the radial growth rate $(\mathrm{mm})$ of the fungus in the confrontation test after the fungus of the control plate reached the entire medium surface. The inhibition ratios were calculated using the following formula: Inhibition ratio $(\%)=$ (radial mycelial growth of control - radial mycelial growth with antagonist) / radial mycelial growth of the control $\times 100$.

\section{Antifungal activity of the cell-free supernatant}

Pure cultures of the bacterial strains were inoculated in liquid Tryptic Soy Broth (TSB), incubated at $28^{\circ} \mathrm{C}$, and constant agitation rate of $90 \mathrm{rpm}$ for $72 \mathrm{~h}$. Afterward, the culture was centrifuged at $6.000 \mathrm{rpm}$, and the supernatant filtered through a $0.22 \mu \mathrm{m}$ pore membrane. Then, streptomycin $(20 \mathrm{mg} / \mathrm{L})$ was added to the supernatant and used as a growth medium for $F$. verticillioides. The TSB medium-plus antibiotic inoculated with culture discs of the fungus, and non-inoculated TSB medium with antibiotic was used as controls. The incubation was performed at $28{ }^{\circ} \mathrm{C}$ without shaking for ten days to allow the mycelial growth off. verticillioides. The fungal mycelium was recovered by filtration on Whatman paper filters (n.4) and dried at $60{ }^{\circ} \mathrm{C}$ until constant weight. The mycelial growth inhibition rate (\%) was determined by the dry weight percentage of the mycelial biomass concerning the control $(100 \%)$.

\section{Effect of cell-free supernatant on conidia germination and hyphae development of $F$. verticillioides}

The bacterial culture filtrates were used to test the inhibitory activity against $F$. verticillioides conidia germination and hyphae growth. Conidia of the fungal pathogen were obtained from a seven-day culture at $25^{\circ} \mathrm{C}$ and $12 \mathrm{~h}$ photoperiod in the BDA medium. The conidia suspension was filtered through gauze to remove any large fragments of mycelia, and the concentration was adjusted to $1 \times 10^{4}$ conidia/mL by counting in a Neubauer chamber. Then, the conidial suspension and each bacterial culture filtrate were mixed in equal proportion and incubated for $24 \mathrm{~h}$ at $26^{\circ} \mathrm{C}$ under a $12 \mathrm{~h}$ photoperiod. The control consisted of TSB medium inoculated with $F$. verticillioides. The effect of each bacterial supernatant on conidia germination and hyphae development was evaluated by observation under an optical microscope. For the conidia germination test, 100 conidia of each treatment were counted, in triplicate, and those germ tubes with twice the size of the conidia were considered germinated (Abou-Jawdah et al. 
2002). The percentages of inhibition were calculated by comparison with the fungal culture without bacterial inoculation (control). The experiment was repeated three times.

\section{Hydrolytic enzymes production by the bacterial strains and calculation of the enzyme index}

The concentration of bacterial culture grown in TSB for $72 \mathrm{~h}$ was adjusted to approximately $10^{8} \mathrm{CFU} \mathrm{mL}$ and inoculated in the specific medium for each enzyme. After microbial growth for about $48 \mathrm{~h}$, the enzymatic activity was measured by a clear zone surrounding colonies. The enzymatic index (EI) was calculated by $\mathrm{El}=$ diameter $(\mathrm{mm})$ of the discolored halo/diameter $(\mathrm{mm})$ of the colonies.

\section{Cellulase}

To determine the cellulase production, the four bacterial strains were grown in minimal $\mathrm{M} 9$ culture medium (10 g/L carboxymethylcellulose, $5 \mathrm{~g} / \mathrm{L}$ yeast extract, $12.8 \mathrm{~g} / \mathrm{L} \mathrm{Na}_{2} \mathrm{HPO}_{4} .7 \mathrm{H}_{2} \mathrm{O}, 3 \mathrm{~g} / \mathrm{L} \mathrm{KH}_{2} \mathrm{PO}_{4}, 0.5$ $\mathrm{g} / \mathrm{L} \mathrm{NaCl}, 1 \mathrm{~g} / \mathrm{L} \mathrm{NH}_{4} \mathrm{Cl}, 5 \mathrm{~g} / \mathrm{L} \mathrm{MgSO}_{4} \cdot 7 \mathrm{H}_{2} \mathrm{O}, 0.01 \mathrm{~g} / \mathrm{L} \mathrm{CaCl}_{2} .2 \mathrm{H}_{2} \mathrm{O}, 15 \mathrm{~g} / \mathrm{L}$ agar). After microbial growth, 10 $\mathrm{mL}$ of Congo Red $(1 \mathrm{~g} / \mathrm{L})$ was distributed on each plate. After $15 \mathrm{~min}$, the plates were washed with $5 \mathrm{M}$ $\mathrm{NaCl}$ and observed for a yellowish area around the colonies (Teather and Wood 1982).

\section{Pectinase}

For pectinase activity, the bacterial strains were grown in the $\mathrm{M} 9$ medium plus citrus pectin with $\mathrm{pH}$ adjusted to 8.0 and incubated as described above. After the culture growth, ten $\mathrm{mL}$ of Lugol were added to the plates and washed with deionized water. A colorless halo around the colonies indicated the pectinase production (Beg et al. 2000).

\section{Protease}

The protease production was evaluated in culture medium containing $5 \mathrm{~g} / \mathrm{L}$ tryptone, $2.5 \mathrm{~g} / \mathrm{L}$ yeast extract, $2.5 \mathrm{~g} / \mathrm{L} \mathrm{NaCl}, 1 \mathrm{~g} / \mathrm{L}$ of glucose, and $16 \mathrm{~g} / \mathrm{L}$ agar. After sterilization, $100 \mathrm{~mL}$ of boiled skimmed milk were distributed on each plate. Protease activity was expressed by the formation of a colorless halo around the colonies (Beg et al. 2000).

\section{Lipase}

For lipase, the four strains were grown in a medium containing $5 \mathrm{~g} / \mathrm{L}$ peptone, $1 \mathrm{~g} / \mathrm{L}$ yeast extract, $4 \mathrm{~g} / \mathrm{L}$ $\mathrm{NaCl}, 15 \mathrm{~g} / \mathrm{L}$ agar, $31.25 \mathrm{~mL} / \mathrm{L}$ olive oil, $0.01 \mathrm{~g} / \mathrm{L}$ rhodamine $B$ with the $\mathrm{pH}$ adjusted to 7.0 . After the bacterial growth, the presence of a blue halo around the colonies was visualized by ultraviolet radiation (Savitha et al. 2007).

\section{Chitinase}

Chitinase activity was performed, as indicated by Trudel and Asselin (1989), with modifications. A 10 $\mu \mathrm{L}$ of the supernatant of bacterial culture was added in a $2 \mathrm{~mm}$ wells in plates containing agarose gel (1.6\%) in sodium acetate buffer $(0.1 \mathrm{M}, \mathrm{pH} 5.0)$ and $0.01 \%(\mathrm{P} / \mathrm{V})$ of glycol chitin solution. After the incubation at 
$30{ }^{\circ} \mathrm{C}$ for $48 \mathrm{~h}$, the plates were stained with $0.1 \%$ calcofluor in $0.5 \mathrm{M}$ Tris-HCL buffer, $\mathrm{pH} 8.9$ for 10 min, and washed with distilled water. The formation of a clear halo detected by ultraviolet light (300nm) was indicative of chitinase production.

\section{Growth of Fusarium verticillioides in maize seeds microbiolized with the bacterial strains}

Maize seeds with no antifungal treatment were disinfested with a 3\% sodium hypochlorite solution for 5 min, followed by a wash with sterile distilled water. Then, the seeds were disinfected according to Daniels (1983) by placing the seeds in a 70\% (v/v) ethanol solution for 10 min and then transferred to flasks containing sterile deionized water for $4 \mathrm{~h}$. Subsequently, the seeds were transferred to another flask containing sterile deionized water and kept in a water bath at $60{ }^{\circ} \mathrm{C}$ for $5 \mathrm{~min}$. Then, the seeds were placed under direct light for $24 \mathrm{~h}$, followed by frozen at $-20{ }^{\circ} \mathrm{C}$ for $24 \mathrm{~h}$ to inhibit seed germination. Afterward, the seeds were infected with a suspension of $1 \times 10^{6}$ conidia/mL of $F$. verticillioides. The antagonist bacterial strains were grown in liquid TSB medium for $72 \mathrm{~h}$, and the bacterial cell concentrations were adjusted to approximately $10^{8} \mathrm{CFU} \mathrm{mL} \mathrm{m}^{-1}$. The maize seeds were microbiolized by immersion in bacterial suspensions for $24 \mathrm{~h}$ at $28{ }^{\circ} \mathrm{C}$ with shaking at $130 \mathrm{rpm}$. The seeds immersed only in TSB served as the negative control. An additional control with seeds disinfected without inoculations was included to assess the effectiveness of the disinfection method. The seeds were germinated in boxes $(11 \times 11 \times 3 \mathrm{~cm})$ containing filter paper, moistened with sterile distilled water. Sixty seeds were distributed in three replicates of 20 seeds per treatment and incubated with a photoperiod of $12 \mathrm{~h}$ of light at $26^{\circ} \mathrm{C}$ for eight days. The evaluation of $F$. verticillioides incidence was carried out by examining the seeds in the Zeiss Stemi 2000 binocular stereomicroscope with a 50X magnification objective.

\section{Effects of seeds microbiolization with bacterial strains in reducing stalk rot disease}

The bacterial strains were grown in Lysogeny Broth (LB) medium at $35^{\circ} \mathrm{C}$ for $72 \mathrm{~h}$ and shaking at 300 rpm. Each culture was centrifuged at $2.000 \mathrm{rpm}$, and the pellet resuspended in a $20 \%$ sucrose solution. For microbiolization, seeds of maize hybrids BRS 1010, susceptible to $F$. verticillioides were treated with bacterial culture plus 50\% sucrose $(\mathrm{w} / \mathrm{vol})$ and incubated at $80 \mathrm{rpm}$ and grown for $30 \mathrm{~min}$ at room temperature. Then, the seeds were mixed in starch and dried for $24 \mathrm{~h}$ at $30{ }^{\circ} \mathrm{C}$ (Figueiredo et al. 2010). The treated seeds were planted in pots containing $5 \mathrm{~kg}$ of soil, and 30 days after planting, the fungus was inoculated by stem punctures using sterile toothpick immersed in the conidial suspension (1 x 106 conidia / $\mathrm{mL}$ ). Five seeds from each treatment were planted in each of three pots. They consisted of 1) seeds treated with each bacterial antagonist inoculated with $F$. verticillioides, 2) seeds without bacterial treatments inoculated with $F$. verticillioides, and 3) seeds without treatment and toothpicks puncture without $F$. verticillioides, As a control, seeds treated with each bacterial strain without $F$. verticillioides inoculation were included in the experiment. After 45 days of infection, the stalk rot severity was determined according to the Symptom Score Scale described by Nicoli et al. (2015).

\section{Statistical analysis}


The analysis of variance (ANOVA) was used to check the collected data, followed by the Scott-Knott means comparison test at $p<0.05$. All experiments were performed in triplicate, and the results were expressed as mean \pm standard deviation (SD).

\section{Results}

\section{Molecular identification of the bacterial strains}

The partial nucleotide sequences of the 16S rRNA gene showed that the four bacterial strains belong to the species Bacillus velezensis (IM14 and CT02), Achromobacter xylosoxidans (ISD04), and Pseudomonas aeruginosa (IPR45). The 16S nucleotide sequences were deposited in the Genbank database, and the accession number are shown in Table 1.

Table 1

Bacterial strains from the maize silks, molecular identification, and Gene Bank accession numbers

\begin{tabular}{|c|c|c|c|c|c|}
\hline Strain & $\begin{array}{l}\text { Collection } \\
\text { place }\end{array}$ & Lifestyle & $\begin{array}{l}\text { Molecular } \\
\text { Identification }\end{array}$ & $\begin{array}{l}\text { Nucleotide } \\
\text { length }\end{array}$ & $\begin{array}{l}\text { Genbank } \\
\text { Acession } \\
\text { number }\end{array}$ \\
\hline ISD04 & Sidrolândia & Endophytic & $\begin{array}{l}\text { Achromobacter } \\
\text { xylosoxidans }\end{array}$ & $1435 b p$ & MK461853 \\
\hline СТ02 & Sete & Epiphytic & Racillus velezensis & 1395bp & MK461847 \\
\hline IPR45 & Sertaneia & Endophytic & Pseudomonas aeruginosa & $1368 \mathrm{bp}$ & MK461572 \\
\hline IM14 & $\begin{array}{l}\text { Sete } \\
\text { Lagoas }\end{array}$ & Epiphytic & Bacillus velezensis & $1400 \mathrm{bp}$ & MK461831 \\
\hline
\end{tabular}

In vitro antifungal activity against Fusarium verticillioides

The four bacterial strains were tested for antagonistic activity against the growth of $F$. verticillioides by the confrontation test. The strain ISD04 (A. xylosoxidans) showed the highest antagonistic activity (100\%) and completely inhibited the fungal development (Fig. 1D). The other three strains CT02 ( $B$. velezensis), IPR45 ( $P$. aeruginosa), and IM14 (B. velezensis) also significantly reduced the $F$. verticillioides growth with inhibition values of $62.5 \%, 61.5 \%$, and $58.5 \%$ respectively. In the three lastmentioned strains, the formation of a clear zone was observed around the colonies (Fig. 1A, 1B, and 1C). Unlike the other three strains, the confrontation test with A. xylosoxidans ISD04 did not show a colorless halo around the colony due to the fast bacterial growth overpassing the fungal disc (Fig. 1D).

Effect of cell-free supernatant on conidia germination and hyphae development of $F$. verticillioides

The results using culture supernatants showed that all strains significantly reduced the mycelial growth of $F$. verticillioides (Fig. 2). The inhibitory effect of the four bacterial antagonists against the fungus was 
assessed through the fungus dry weight. The inhibitory values ranged from 47.2 to $74.7 \%$, with no significant differences (Table 2).

The four strains showed different percentages of conidia germination inhibition compared to the control inoculated with $F$. verticillioides, which presented $86.6 \%$ of germination, and the cell-free filtrate Pseudomonas aeruginosa (IPR45) inhibited 100\% the conidial germination. The other strains showed inhibition values varying from $45-56.5 \%$ (Table 2 ).

Table 2

Inhibition of mycelial growth and conidia germination of $F$. verticillioides by cell-free supernatant

\begin{tabular}{|c|c|c|c|c|c|}
\hline Strain & Identification & $\begin{array}{l}\text { Mycelial } \\
\text { mass } \\
(\mathrm{mg})^{*}\end{array}$ & $\begin{array}{l}\text { Mycelial } \\
\text { inhibition } \\
(\%)\end{array}$ & $\begin{array}{l}\text { Conidia } \\
\text { germination } \\
(\%)\end{array}$ & $\begin{array}{l}\text { Conidia } \\
\text { germination } \\
(\%)\end{array}$ \\
\hline Control $^{\star \star}$ & - & $367.6 \mathrm{a}$ & - & 86.6 a & - \\
\hline ISD04 & $\begin{array}{l}\text { A. } \\
\text { xylosoxidans }\end{array}$ & 194.0 b & 47.2 & $42.6 \mathrm{~b}$ & 50.8 \\
\hline IM14 & B. velezensis & $147.3 \mathrm{~b}$ & 59.9 & $37.6 \mathrm{c}$ & 56.5 \\
\hline IPR45 & P. aeruginosa & $99.6 \mathrm{~b}$ & 72.9 & $00.0 \mathrm{~d}$ & 100.0 \\
\hline СТ02 & B. velezensis & $93.0 \mathrm{~b}$ & 74.7 & $47.6 \mathrm{~b}$ & 45.0 \\
\hline
\end{tabular}

The microscopic evaluation showed that the filtered supernatant of Bacillus velezensis (strains IM14 and CT02) impaired the hyphal growth of $F$. verticillioides and caused morphological abnormalities, such as hyphal swelling, reduction in the hyphal compartment length (shortening), and vacuolization (Fig. 3C, 3D and $3 \mathrm{E}$ ). In addition, the culture filtrate of $P$. aeruginosa (isolate IPR45) completely inhibited the conidial germination and considerably reduced the number of the fungal conidia in suspension (Fig. 3F). Normal hyphal growth was observed in control with TSB medium (Fig. 3A) and A. xylosoxidans culture filtrate (Fig. 3B) after 24h incubation.

\section{Hydrolytic enzymes production by the bacterial strains and calculation of the enzyme index}

In this study, the four bacterial strains produced at least one of the five enzymes tested (Table 3 and Fig. 4). All strains produced chitinase; three produced protease (IM14, IPR45, and CT02), two produced cellulase and pectinase (IM14 and CT02). Only the isolate IPR45 of $P$. aeruginosa showed lipolytic activity, and the highest chitinolytic activity (Table 3 ). 
Table 3

Enzymatic index (EI) of cellulase, pectinase, protease, lipase, and chitinase of the bacterial cultures A. xylosoxidans, B. velezensis, P. aeruginosa, and B. velezensis

\begin{tabular}{|lllllll|}
\hline Isolate & Identification & \multicolumn{5}{l|}{ Enzimatic Index (EI) } \\
\hline & & Cellulase & Pectinase & Protease & Lipase & Chitinase \\
\hline ISD04 & A. xylosoxidans & 0.00 & 0.00 & 0.00 & 0.00 & $5.40 \mathrm{a}$ \\
\hline IM14 & B. velezensis & $1.40 \mathrm{a}$ & $1.91 \mathrm{~b}$ & $1.31 \mathrm{a}$ & 0.00 & $1.60 \mathrm{~b}$ \\
\hline IPR45 & P. aeruginosa & 0.00 & 0.00 & $1.46 \mathrm{a}$ & 2.30 & $5.70 \mathrm{a}$ \\
\hline CT02 & B. velezensis & $1.66 \mathrm{~b}$ & $1.88 \mathrm{~b}$ & $1.55 \mathrm{a}$ & 0.00 & $1.80 \mathrm{~b}$ \\
\hline *Averages followed by the same letter do not differ by the Scott-Knott test at 5\% probability \\
\hline
\end{tabular}

\section{Growth of Fusarium verticillioides in maize seeds microbiolized with the bacterial strains}

The growth of microorganisms was not observed in the control treatment consisting of disinfected seeds, which confirmed the disinfection method (Fig. 5A). Contrary, the fungal growth was remarkable in control inoculated with $F$. verticillioides conidia (Fig. 5B).

The microbiolization of seeds with the four bacterial strains was efficient in reducing the fungal incidence compared with the non-microbiolized seeds inoculated with $F$. verticillioides. The seeds treated with Pseudomonas aeruginosa, the growth of the pathogen was completely inhibited (Fig. 5C). The seeds treated separately with the two Bacillus velezensis (Fig. 5D and 5E) and Achromobacter xylosoxidans (Fig. $5 \mathrm{~F}$ ) only partially reduced the growth of $F$. verticillioides.

\section{Effects of seeds microbiolization with bacterial strains in reducing stalk rot disease}

The severity of the stalk rot disease was evaluated by the presence of black or dark brown lesions in maize stalk, a typical diagnostic of $F$. verticillioides infection (Fig. 6). The disease severity in each treatment and the antagonistic effect of the bacterial strains on the percentage of stalk rot reduction are shown in Table 4. Plants treated with A. xylosoxidans showed $72.6 \%$ in the reduction of the stalk rot prevalence (Fig. $6 \mathrm{C}$ ), and the effect of the treatment was statistically equal to control without inoculation with $F$. verticillioides (Fig. 6A). The strains of $P$. aeruginosa (IPR45) and B. velezensis (CT02) reduced the stalk rot by $50.7 \%$ and $32.8 \%$, respectively (Fig. $6 \mathrm{D}$ and $6 \mathrm{~F}$ ), compared with the control inoculated with $F$. verticillioides (Fig. 6B). Microbiolization with $B$. velezensis IM14 did not affect disease progression and was not statistically different from the control inoculated with the fungus (Fig. 6E). Microbiolized seeds without $F$. verticillioides inoculation were germinated and developed health plants without stalk rot symptoms (data not shown). 
Table 4

Effect of seeds microbiolization with four bacterial strains in reducing stalk rot severity fortyfive days after Fusarium verticillioides inoculation under greenhouse conditions

Treatment
Disease severity

$(\%)^{*}$

$6.02 \mathrm{a}$

$38.06 \mathrm{c}$

$10.40 \mathrm{a}$

$18.75 b$

$50.05 \mathrm{c}$

$25.57 \mathrm{~b}$
Stalk rot reduction

(\%)

0

72.6

50.7

0

32.8

* Averages followed by the same letter do not differ by the Scott-Knott test at $5 \%$ probability

\section{Discussion}

Fungal diseases are a major threat to crop production. Fusarium verticillioides is the primary pathogen of maize and cause ear rot, stalk rot, and a fumonisin producer making the grains improper for human and animal consumption (Rosa Junior et al. 2019). The use of chemical pesticides in the field is a serious threat to environmental and human health (Zubrod et al. 2019). Therefore, biological control is a natural alternative to reducing production costs and environmental disturbances, thereby contributing to sustainable agriculture (Jia 2019). Thus, developing strategies using antagonistic microorganisms represents a safer and cheaper solution to control fungal diseases in crop fields (Dukare et al. 2019). In this work, we aimed to test four bacterial strains isolated from the maize silks to obtain biocontrol agents against the maize phytopathogenic fungus $F$. verticillioides. The fungus $F$. verticillioides growing along or within the stigmatic structures (silks), in association with the pollen tube, gain access to the plant, causing kernel rot and ear rot, and producing fumonisins (Munkvold et al. 1997; Gai et al. 2018). The use of microorganisms from the environment where they will be used guarantees easy adaptation and survival of the antagonists for in vivo interactions against the target pathogen and indigenous microorganisms (Figueroa-López et al. 2016). F. verticillioides may also enter the plant through the roots. Thus, seeds microbiolized with bacterial antagonists may reduce the levels of plant infection by the fungus. Therefore, adopting these strategies tends to increase biological control efficiency and represent a key point for developing new strategies for plant disease management.

We demonstrated the antagonistic activity of four bacteria isolated from the maize silks against $F$. verticillioides and carried out their identification by DNA sequencing. The four bacterial strains belong to Bacillus velezensis, Pseudomonas aeruginosa, and Achromobacter xylosoxidans (former Alcaligenes xylosoxidans). Several studies have shown the potential of these species as biocontrol agents for different phytopathogenic fungi, including Fusarium sp. (Borah et al. 2016; Moretti et al. 2008; Passari et 
al. 2017). The complete genome sequence and laboratory experiments on purification of the bioactive substances revealed that these three species produce several inhibitory substances (as the antifungal cyclic lipopeptide bacillomycin L, Cyclo (I-Leucyl-I-Prolyl), and several phenazines produced by Bacillus velezensis, Achromobacter xylosoxidans and Pseudomonas aeruginosa, respectively (Stover et al. 2000; Yan et al. 2004; Kumar et al. 2005; Badalamenti and Hunter 2015; Zhang et al. 2020; Gao et al. 2020). Furthermore, many strains in these groups are notable plant growth promoters by producing phytohormones, organic acids, enzymes, and siderophores, or activating mechanisms for mineral phosphate solubilization and nitrogen fixation (Keswani et al. 2020).

In the in vitro confrontation method, all four strains showed high inhibitory activity against $F$. verticillioides. The antagonistic control may occur through different mechanisms of action such as the production of antifungal substances as organic acids, lytic enzymes, hydrogen peroxide, diacetyl, and peptides (Piard and Desmazeaud 1992; Krishan et al. 2018; Souza et al. 2018). Our results showed that cell-free supernatants reduced the germination of conidia and caused morphological changes in the structure of $F$. verticillioides hyphae. As the primary mode of vegetative growth of the fungus, the hyphae play a crucial role in fungal adhesion, invasion, and disease progression in the plant. Morphological damages to the hyphae caused by bacterial metabolites reduce the pathogenicity by preventing the plant colonization by the fungus (Borah et al. 2016).

The inhibitory effect of both cell-free culture supernatants and microbiolized seeds from $P$. aeruginosa reduced the number of conidia of $F$. verticillioides, and the fungus growth affecting the development of the hyphae and altering the conidial cell wall. A previous study by Chan et al. (2003) reported the negative effect of Bacillus subtilis culture supernatant on macroconidia germination and hyphal growth of $F$. graminearum due to hyphal swelling and cell disruptions.

The presence of active substances in the filtered supernatant of the strain СT02 of Bacillus velezensis reduced the growth of $F$. verticillioides by $74.7 \%$. Since the discovery of $B$. velezensis genes controlling the biosynthesis of secondary metabolites with activity in suppressing the growth of plant pathogens by triggering the systemic resistance induced in plants and plant growth, the species has received considerable attention from the biological control research community (Chen et al. 2018; Rabbee et al. 2019). The complete genome sequencing of the strain B-4 of Bacillus velezensis by Zhu et al. (2020) revealed 12 clusters of genes related to the synthesis of antimicrobial metabolites corresponding to more than $19.56 \%$ of the genome. Among the primary metabolites with antimicrobial properties of $B$. velezensis, cyclic lipopeptides may be highlighted, such as iturin $A$, fengycin, and surfactin. Phenicin has toxic activity against filamentous fungi and can induce plant resistance, and surfactin acts as a biosurfactant and induces systemic resistance (Gong et al. 2015; Kim et al. 2017). Iturin, which acts in the cytoplasmatic membrane leading the cell to death, shows intense antifungal activity against yeasts and many fungi (Ongena and Jacques 2008). The use of CT02 and other Bacillus species in biocontrol programs represents an advantage concerning the other three strains due to their ability to produce endospores resistant to heat and drying. These features give survival advantages under field conditions and make these microorganisms more suitable for commercial formulations due to their increased shelf 
life compared to the lifetime of agrochemicals (Wu et al. 2015). For these reasons, several Bacillus-based products are commercially available in the supermarket (Pérez-Garcia et al. 2011).

The excretion of hydrolytic enzymes can weaken or degrading the components of the fungal cell walls and membranes (Neeraja et al. 2010). Proteases can bind to external mannoproteins and open the protein structure, exposing the inner layers of glucan and chitin microfibrils (Choudhary et al. 2014). The enzymes chitinase, glucanase, and protease produced by some bacterial strains can hydrolyze the fungal cell wall but not the plant cell wall, which is the most critical target of fungal pathogens (Neeraja et al. 2010; Khare and Yadav 2017). Other forms of enzymatic actions occur when the endophyte produces cellulase and pectinase, activating the plant defense responses, or when proteases inactivate the enzymes of the pathogen responsible for the destruction of the plant cell wall, which is the determinant factor for plant infection by the fungus (Vaidya et al. 2001; Khare and Yadav 2017; Köhl et al. 2019).

In the test of extracellular enzyme production, only Pseudomonas aeruginosa showed lipolytic activity. Chalotra et al. (2019) reported the effect of secreted lipase degrading the fungal cell wall. Together with the other results for $P$. aeruginosa, this suggests the existence of different antifungal mechanisms exerting synergism or cooperative effects to reduce the growth of $F$. verticillioides. Many strains of $P$. aeruginosa have been used in commercial formulations for the biocontrol of diseases caused by Phytophtora spp., Phythium spp., Rhizoctonia spp., and Fusarium spp. and other fungi in many crop species such as tomatoes, pepper, taro, and beans (Kumar et al. 2005; Wu et al. 2015; Zohara et al. 2015; Meena et al. 2019). However, studies using $P$. aeruginosa in $F$. verticillioides biological control in maize crops are still scarce.

In the greenhouse, Achromobacter xylosoxidans ISD04 reduced the severity of the stalk rot disease, producing a result similar to the control not inoculated with $F$. verticillioides. It was demonstrated that plants treated with A. xylosoxidans strain AUM54, followed by inoculation with Magnaporthe oryzae (rice blast fungus), showed a significant increase in the activities of defense-related enzymes such as polyphenol oxidase, peroxidase, phenylalanine ammonia-lyase, and chitinase (Joe et al. 2012). The authors (Joe et al. 2012) also reported that plants treated with A. xylosoxidans AUM54 showed a reduced incidence of blast disease and significant growth improvement.

Despite the satisfactory results in vitro, the performance of Bacillus velezensis IM14 in the greenhouse not differed statistically from the control inoculated with $F$. verticilioides. Various studies have shown that antifungal activity in vitro does not necessarily correlate with antagonistic activities in situ (von der Weid et al. 2000; Gopalakrishnan et al. 2011; Köhl et al. 2019; Wang et al. 2019). This finding has been attributed to the fact that the production of antifungal metabolites is determined by more than one mechanism regulated by highly complex interactions among their components, such as the inoculum, the abiotic environment, and the other organisms living in the soil (Watanabe et al. 2001). In this scenario, the antagonist must quickly adapt to a new environment, and its success or failure will depends on its competitive ability for space and nutrients. Thus, the possibility exists that the introduced species may eventually be eliminated from the environment. Chan et al. (2003) presented an alternative solution to 
circumvent this problem by applying cell-free culture filtrate to the soil instead of the living cells. This procedure avoids the need for the antagonist to colonize the target plant and eliminates the influence of external factors but decreases the efficiency of the biological control. In addition, this strategy does not eliminate the harmful effects of cell-free culture extracts on the soil microorganisms, and the protective effect of the antagonist will not extend to adult uncolonized plants or the maize kernels. Thus, this critical aspect of biological control remains unanswered. The use of bacterial antifungal metabolites in chemosensitization, instead of the living bacteria, is a promising topic to increase the effectiveness of fungicides by exploring the synergistic action of fungicides and antifungal metabolites and, at the same time, decreasing the risks of negative impact on the environment by reducing the amount of fungicide applied in the field (Kim et al. 2017). Therefore, to solve this limitation, it is undoubtedly necessary to move forward in the biological control approaches by identifying, purifying, and synthesizing the active metabolites and their application to the target. Recently was demonstrated that mycelia of $F$. verticillioides treated with rhamnolipids from $P$. aeruginosa exhibited an irregular shape, surface roughness, breakages, and severe reduction in thickness, leading to suppression of disease symptoms and colonization of maize plants by F. verticillioides (Borah et al. 2016). Future studies within these four strains will address this topic.

\section{Conclusions}

The data showed the inhibitory effect of four endophytic and epiphytic bacterial strains from maize silks on Fusarium verticillioides. All strains evaluated produced at least one of the five hydrolytic enzymes.

Supernatants free from Bacillus velezensis cells caused morphological abnormalities in the phytopathogen hyphae. Pseudomonas aeruginosa inhibited the growth of $F$. verticillioides in microbiolized seeds. In the greenhouse, Achromobacter xylosoxidans ISD04, Pseudomonas aeruginosa IPR45, and Bacillus velezensis CT02 were effective in reducing the maize stalk rot. The four strains are a potential source for control strategies to reduce the $F$. verticillioides incidence in maize.

\section{Declarations}

\section{Funding}

This work was financially supported by Embrapa Maize and Sorghum (CNPMS), CNPq and UFSJ.

\section{Conflicts of interest/Competing interests}

The authors declare that they have no conflict of interests.

\section{Availability of data and material}

Not applicable

\section{Code availability}


Not applicable

\section{Authors' contribution}

This study was designed by Christiane Abreu de Oliveira Paiva, Gisele de Fátima Dias Diniz, Luciano Viana Cota, Vera Lúcia dos Santos, and Ivanildo Evódio Marriel. Christiane Abreu de Oliveira Paiva and Ivanildo Evódio Marriel, as the main investigators directed and coordinated all aspects of the project. Frederick Mendes Aguiar and Dagma Dionísia da Silva assisted Gisele de Fátima Dias Diniz in the experiments and collecting the samples. Gisele de Fátima Dias Diniz performed the data analysis and, together with José Edson Fontes Figueiredo and Christiane Abreu de Oliveira, did critical review of the results and manuscript. The article was written by Gisele de Fátima Dias Diniz and José Edson Fontes Figueiredo.

\section{Ethics approval}

The experiments reported in this study did not involve human participants and/or animals.

\section{Consent to participate}

Not applicable

\section{Consent for publication}

All authors read and approved the final version of the manuscript for publication.

\section{References}

1. Abou-Jawdah Y, Sobh H, Salameh A (2002) Antimycotic activities of selected plant flora, growing wild in Lebanon, against phytopathogenic fungi. Journal of Agricultural and Food Chemistry 50:3208-3213. https://doi.org/10.1021/jf0115490

2. Badalamenti JP, Hunter RC (2015) Complete Genome Sequence of Achromobacter xylosoxidans MN001, a Cystic Fibrosis Airway Isolate. Genome Announcements 3(4):e00947-15. https://doi.org/10.1128/genomeA.00947-15

3. Beg QK, Bhushan B, Kapoor M, Hoondal GS (2000) Production and characterization of thermostable xylanase and pectinase from Streptomyces sp. QG-11-3. Journal of Industrial Microbiology and Biotechnology 24(6): 396-402. https://doi.org/10.1038/sj.jim.7000010

4. Blacutt AA, Gold SE, Voss KA, Gao M, Glenn AE (2018) Fusarium verticillioides: Advancements in understanding the toxicity, virulence, and niche adaptations of a model mycotoxigenic pathogen of maize. Phytopathology 108:312-326. https://doi.org/10.1094/PHYTO-06-17-0203-RVW

5. Borah SN, Goswami D, Sarma HK, Cameotra SS, Deka S (2016) Rhamnolipid biosurfactant against Fusarium verticillioides to control stalk and ear rot disease of maize. Frontiers in Microbiology 7:1505. https://doi.org/10.3389/fmicb.2016.01505 
6. Chalotra R, Mallick SA, Gupta M, Sharma D, Gupta S (2019) Production of cell wall degrading enzymes and antibiotic by pseudomonads for assessing their biocontrol potential. Indian Journal of Agricultural Sciences 89(6): 994-997.

7. Chan YK, McCormick WA, Seifert KA (2003) Characterization of an antifungal soil bacterium and its antagonistic activities against Fusarium species. Canadian Journal of Microbiology 49:253-262. https://doi.org/10.1139/w03-033

8. Chen L, Heng J, Qin S, Bian K (2018) A comprehensive understanding of the biocontrol potential of Bacillus velezensis LM2303 against Fusarium head blight. PLOS ONE 13(6):e0198560. https://doi.org/10.1371/journal.pone.0198560

9. Choudhary B, Nagpure A, Gupta RK (2014) Fungal cell-wall lytic enzymes, antifungal metabolite(s) production, and characterization from Streptomyces exfoliatus MT9 for controlling fruit-rotting fungi. Journal of Basic Microbiology 54:1295-1309. https://doi.org/10.1002/jobm.201400380

10. Daniels BA (1983) Elimination of Fusarium moniliforme from corn seed. Plant Disease 67:609-611. https://doi.org/10.1094/PD-67-609

11. Deepa N, Sreenivasa MY (2017) Fusarium verticillioides, a Globally Important Pathogen of Agriculture and Livestock: A Review. Journal of Veterinary Medicine and Research 4(4)1084-1091.

12. Devi S, Kiesewalter HT, Kovács R, Frisvad JC, Weber T, Larsen TO, Kovács AT, Ding L (2019) Depiction of secondary metabolites and antifungal activity of Bacillus velezensis DTU001. Synthetic and Systems Biotechnology 4:142-149. https://doi.org/10.1016/j.synbio.2019.08.002

13. Dhaouadi S, Rouissi W, Mougou-Hamdane A, Nasraoui B (2018) Evaluation of biocontrol potential of Achromobacter xylosoxidans against Fusarium wilt of melon. European Journal of Plant Pathology 154:179-188. https://doi.org/10.1007/s10658-018-01646-2

14. Dharni S, Alam M, Kalani K, Khaliq A, Samad A, Srivastava SK, Patra DD (2012) Production, purification, and characterization of antifungal metabolite from Pseudomonas aeruginosa sd12, a new strain obtained from tannery waste polluted soil. Journal of Microbiology and Biotechnology 22:674-683. https://doi.org/10.4014/jmb.1109.09061

15. Dukare AS, Paul S, Nambi VE, Gupta RK, Singh R, Sharma K, Vishwakarma RK (2019) Exploitation of microbial antagonists for the control of postharvest diseases of fruits: a review. Critical Reviews in Food Science and Nutrition 59:1498-1513. https://doi.org/10.1080/10408398.2017.1417235

16. Figueiredo JEF, Teixeira MA, Lima GVC, Quintão PL, Correa JA, Bressan W, Pinto NFJ, Casela CR (2010) Atividade antagonista da bactéria endofítica CNPMS22 contra fungos de sementes do milho (Zea mays). Publishing Associação Brasileira de Milho e Sorgo, ABMS. https://www.alice.cnptia.embrapa.br/alice/bitstream/doc/865369/1/0052.pdf. Accessed 26 June 2020

17. Figueroa-López AM, Cordero-Ramírez JD, Martínez-Álvarez JC, López-Meyer M, Lizárraga-Sánchez GJ, Félix-Gastélum R, Castro-Martínez C, Maldonado-Mendoza IE (2016) Rhizospheric bacteria of maize with potential for biocontrol of Fusarium verticillioides. Springer Plus 5:330. https://doi.org/10.1186/s40064-016-1780-x 
18. Gai X, Dong H, Wang S, Liu B, Zhang Z, Li X, Gao Z (2018) Infection cycle of maize stalk rot and ear rot caused by Fusarium verticillioides. PLoS One 13:e0201588.

https://doi.org/10.1371/journal.pone.0201588

19. Gao C, Wang Y, Zhang Y, Wei J, Cheng X, Zhang J, Zou Q, Gu J (2020) Complete Genome Sequence of Pseudomonas aeruginosa XN-1, Isolated from the Sputum of a Severe Pneumonia Patient. Microbiology Resource Announcements 9(36):e00653-20. https://doi.org/10.1128/MRA.00653-20.

20. Gong A D, Li HP, Yuan QS, Song XS, Yao W, He WJ, Zhang JB, Liao YC (2015) Antagonistic Mechanism of Iturin A and Plipastatin A from Bacillus amyloliquefaciens S76-3 from Wheat Spikes against Fusarium graminearum. Plos ONE, 10(2), e0116871.

https://doi.org/10.1371/journal.pone.0116871

21. Gopalakrishnan S, Humayun P, Kiran BK, Kannan IGK, Vidya MS, Deepthi K, Rupela O (2011) Evaluation of bacteria isolated from rice rhizosphere for biological control of charcoal rot of sorghum caused by Macrophomina phaseolina (Tassi) Goid. World Journal of Microbiology and Biotechnology 27:1313-1321. https://doi.org/10.1007/s11274-010-0579-0.

22. Haq UI, Sarwar MK, Faraz A, Latif MZ (2020) Synthetic chemicals: Major component of plant disease management. In: Ul Haq I, ljaz S (eds) Plant Disease Management Strategies for Sustainable Agriculture through Traditional and Modern Approaches, Sustainability in Plant and Crop Protection, vol 13. Springer, Cham, pp 53-81. https://doi.org/10.1007/978-3-030-35955-3_4

23. Hornby D (1983) Suppressive soils. Annual Review of Phytopathology 21:65-85. https://doi.org/10.1146/annurev.py.21.090183.000433

24. Jadhav HP, Shaikh SS, Sayyed RZ (2017) Role of hydrolytic enzymes of rhizoflora in biocontrol of fungal phytopathogens: an overview. In: Mehnaz S (ed) Rhizotrophs: Plant growth promotion to bioremediation. Springer, Singapore, pp 183-203. https://doi.org/10.1007/978-981-10-4862-3_9

25. Jia H (2019) Agriculture: science and technology safeguard sustainability. National Science Review 6:595-600. https://doi.org/10.1093/nsr/nwz036

26. Joe MM, Islam MDR, Karthikeyan B, Bradeepa K, Sivakumaar PK, Sa T (2012) Resistance responses of rice to rice blast fungus after seed treatment with the endophytic Achromobacter xylosoxidans AUM54 strains. Crop Protection 42:141-148. https://doi.org/10.1016/j.cropro.2012.07.006

27. Keswani C, Singh HB, García-Estrada C, Caradus L, He YW, Mezaache-Aichour S, Glare TR, Borriss R, Sansinenea E (2020) Antimicrobial secondary metabolites from agriculturally important bacteria as next-generation pesticides. Applied Microbiology and Biotechnology 104:1013-1034. https://doi.org/10.1007/s00253-019-10300-8

28. Khare E, Yadav A (2017) The role of microbial enzyme systems in plant growth promotion. Climate Change and Environmental 5:122-145. https://doi.org/10.5958/2320-642X.2017.00013.8

29. Kim K, Lee Y, Ha A, Kim J, Park AR, Yu NH, Son H, Choi GJ, Park HW, Lee CW, Lee T, Lee YW, Kim JC (2017) Chemosensitization of Fusarium graminearum to chemical fungicides using cyclic lipopeptides produced by Bacillus amyloliquefaciens strain JCK-12. Frontiers in Plant Science 8:2010 https://doi.org/10.3389/fpls.2017.02010 
30. Köhl J, Kolnaar R, Ravensberg WJ (2019) Mode of action of microbial biological control agents against plant diseases: Relevance beyond efficacy. Frontiers in Plant Science 10:845. https://doi.org/10.3389/fpls.2019.00845

31. Krishan KC, Rajput R, Sharma R (2018) Antagonistic activity of bacterial species isolated from soil against fungi. World Journal of Pharmaceutical Research 7(9):760-767. https://doi.org/10.20959/wjpr20189-11979

32. Kumar RS, Ayyadurai N, Pandiaraja P, Reddy AV, Venkateswarlu Y, Prakash O, Sakthivel N (2005) Characterization of antifungal metabolite produced by a new strain Pseudomonas aeruginosa PUPa3 that exhibits broad-spectrum antifungal activity and biofertilizing traits. Journal of Applied Microbiology 98:145-154. https://doi.org/10.1111/j.1365-2672.2004.02435.x

33. Manuel J, Berry C, Selin C, Fernando WGD, Kievit TR (2011) Repression of the antifungal activity of Pseudomonas sp. strain DF41 by the stringent response. Applied and Environmental Microbiology 77:5635-5642. https://doi.org/10.1128/AEM.02875-1038.

34. Meena KS, Annamalai M, Prabhukarthikeyan SR, Keerthana U, Yadav MK, Jena RM, Prajna P (2019) Agriculture Application of Pseudomonas: A view on the relative antagonistic potential against pests and diseases. In: Kumar A, Meena VS, (eds) Plant Growth Promoting Rhizobacteria for Agricultural sustainability: From theory to practices. Springer Nature, Singapore, pp 67-76. https://doi.org/10.1007/978-981-13-7553-8

35. Moretti M, Gilardi G, Gullino ML, Garibaldi A (2008) Biological Control Potential of Achromobacter xylosoxydans for Suppressing Fusarium wilt of Tomato. International Journal of Botany 4:369-375. http://doi.org/10.3923/ijb.2008.369.375

36. Munkvold GP, Mcgee DC, Carlton WM (1997) Importance of different pathways for maize kernel infection by Fusarium moniliforme. Phytopathology 87:209-217. https://doi.org/10.1094/PHYT0.1997.87.2.209

37. Neeraja C, Anil K, Purushotham P, Suma K, Sarma P, Moerschbacher BM, Podile AR (2010) Biotechnological approaches to develop bacterial chitinases as a bioshield against fungal diseases of plants. Critical Reviews in Biotechnology 30:231-241. https://doi.org/10.3109/07388551.2010.487258

38. Nicoli A, Costa RV, Cota LV, Silva DD, Zambolim L, Lanza FE, Guimarães DP, Landau EC (2015) Diagrammatic scale validation to quantify the severity of anthracnose stalk in corn. Ciência Rural 45:1720-1726. https://doi.org/10.1590/0103-8478cr20141510

39. Ongena M, Jacques $P$ (2008) Bacillus lipopeptides: Versatile weapons for plant disease biocontrol. Trends in Microbiology 16:115-125. https://doi.org/10.1016/j.tim.2007.12.009

40. Passari AK, Lalsiamthari PC, Zothanpuia, Leo VV, Mishra VK, Yadav MK, Gupta VK, Singh BP (2017) Biocontrol of Fusarium wilt of Capsicum annuum by rhizospheric bacteria isolated from turmeric endowed with plant growth promotion and disease suppression potential. European Journal of Plant Pathology 150:831-846. https://doi.org/10.1007/s10658-017-1325-3 
41. Pérez-Garcia A, Romero D, de Vicente A (2011) Plant protection and growth stimulation by microorganisms: Biotechnological applications of Bacilli in agriculture. Current Opinion in Biotechnology 22:187-193. https://doi.org/10.1016/j.copbio.2010.12.003

42. Piard JC, Desmazeaud M (1992) Inhibiting factors produced by lactic acid bacteria. 2. Bacteriocins and other antibacterial substances. Le Lait 72 (2):113-142. https://doi.org/10.1051/lait:199229

43. Poritsanos N, Selin C, Fernando WGD, Nakkeeran S, de Kievit TR (2006) A GacS deficiency does not affect Pseudomonaschlororaphis PA23 fitness when growing on canola, in aged batch culture or as a biofilm. Can. J. Microbiol. 52: 1177-1188. https://doi.org/10.1139/W06-079

44. Rabbee MF, Ali Md S, Choi J, Hwang BS, Jeong SC, Baek K-y (2019) Bacillus velezensis: A valuable member of bioactive molecules within plant microbiomes. Molecules 24:1046.

https://doi.org/10.3390/molecules24061046

45. Rahman SFSA, Singh E, Pieterse CMJ, Schenk PM (2017) Emerging microbial biocontrol strategies for plant pathogens. Plant Science 267:102-111. https://doi.org/10.1016/j.plantsci.2017.11.012

46. Rosa Junior OF, Dalcin MS, Nascimento VL, Haesbaert FM, Ferreira TPS, Fidelis RR, Sarmento RA, Aguiar RWS, Oliveira EE, Santos GR (2019) Fumonisin production by Fusarium verticillioides in maize genotypes cultivated in different environments. Toxins 11:215.

https://doi.org/10.3390/toxins11040215

47. Savitha J, Srividya S, Jagat R, Payal P, Priyanki S, Rashmi GW, Roshini KT, Shantala YM (2007) Identification of potential fungal strains for the production of inducible, extracellular and alkalophilic lipase. African Journal of Biotechnology 6:564-568. https://doi.org/10.5897/AJB2007.000-2048

48. Shtark OY, Shaposhnikov Al, Kravchenko LV (2003) The production of antifungal metabolites by Pseudomonas chlororaphis grown on different nutrient sources. Microbiology 72:574-578. https://doi.org/10.1023/A:1026047301457

49. Souza CG, Martins FICC, Zocolo GJ, Figueiredo JEF, Canuto KM, Brito ES (2018) Simultaneous quantification of lipopeptide isoforms by UPLC-MS in the fermentation broth fom Bacillus Subtilis CNPMS22. Anal Bioanal Chemistry 410(26):6827-6836. https://doi/org/10.1007/s00216-018-1281-6

50. Stover CK, Pham XQ, Erwin AL, Mizoguchi SD, Warrener P, Hickey MJ, Brinkman FSL, Hufnagle WO, Kowalik DJ, Lagrou M, Garber RL, Goltry L, Tolentino E, Westbrock-Wadman S, Yuan Y, Brody LL, Coulter SN, Folger KR, Kas A, Larbig K, Lim R, Smith K, Spencer D, Wong GKS, Wu Z, Paulsen IT, Reizer J, Saier MH, Hancock REW, Lory S, Olson MV (2000) Complete genome sequence of Pseudomonas aeruginosa PA01, an opportunistic pathogen. Nature 406: 959-964 https://doi.org/10.1038/35023079

51. Teather RM, Wood PJ (1982) Use of congo red polysaccharide interactions in enumeration and characterization of cellulolytic bacteria from the bovine rumen. Applied and Environmental Microbiology 43:777-780. https://doi.org/0099-2240/82/040777-04\$02.00/0

52. Tilocca B, Cao A, Migheli Q (2020) Scent of a killer: Microbial volatilome and its role in the biological control of plant pathogens. Frontiers in Microbiology 11:41. https://doi.org/10.3389/fmicb.2020.00041 
53. Trudel J, Asselin A (1989) Detection of chitinase activity after polyacrylamide gel electrophoresis. Analytical Biochemistry 178:362-366. https://doi.org/10.1016/0003-2697(89)90653-2

54. Turner S, Pryer KM, Miao VPW, Palmer JD (1999) Investigating deep phylogenetic relationships among cyanobacteria and plastids by small subunit rRNA sequence analysis. Journal of Eukaryotic Microbiology 46:327-338. https://doi.org/10.1111/j.1550-7408.1999.tb04612.x

55. Vaidya RJ, Shah IM, Vyas PR, Chhatpar HS (2001) Production of chitinase and its optimization from a novel isolate Alcaligenes xylosoxydans: Potential in antifungal biocontrol. World Journal of Microbiology and Biotechnology 17:691-696. https://doi.org/10.1023/A:1012927116756

56. Veliz EA, Martínez-Hidalgo P, Hirsch AM (2017) Chitinase-producing bacteria and their role in biocontrol. AIMS Microbiology 3:689-705.

57. von der Weid I, Paiva E, Nóbrega A, van Elsas JD, Seldin L (2000) Diversity of Paenibacillus polymyxa strains isolated from the rhizosphere of maize planted in Cerrado soil. Research in Microbiology 151(5):369-381. https://doi.org/10.1016/s0923-2508(00)00160-1.

58. Vyas P, Kumar D, Dubey A, Kumar A (2018) Screening and characterization of Achromobacter xylosoxidans isolated from rhizosphere of Jatropha curcas L. (Energy Crop) for plant-growthpromoting traits. Journal of Advanced Research in Biotechnology 3:1-8. http://doi.org/10.15226/2475-4714/3/1/00134

59. Yan PS, Song Y, Sakuno E, Nakajima H, Nakagawa H, Yabe K (2004) Cyclo(L-leucyl-L-prolyl) produced by Achromobacter xylosoxidans inhibits aflatoxin production by Aspergillus parasiticus. Appl Environ Microbiology 70(12):7466-7473. http://doi.org/ 10.1128/AEM.70.12.7466-7473.2004

60. Yoon MY, Cha B, Kim JC (2013) Recent Trends in Studies on Botanical Fungicides in Agriculture. The Plant Pathology Journal 29:1-9. https://doi.org/10.5423/PPJ.RW.05.2012.0072

61. Wang X, Li Q, Sui J, Zhang J, Liu Z, Du J, Xu R, Zhou Y, Liu X (2019) Isolation and Characterization of Antagonistic Bacteria Paenibacillus jamilae HS-26 and Their Effects on Plant Growth. BioMed Research International 3638926. https://doi.org/10.1155/2019/3638926

62. Watanabe K, Kodama Y, Harayama S (2001) Design and evaluation of PCR primers to amplify bacterial $16 \mathrm{~S}$ ribosomal DNA fragments used for community fingerprinting. Journal of Microbiological Methods 44(3):253-262. https://doi.org/10.1016/S0167-7012(01)00220-2.

63. Wu L, Wu H-J, Qiao J, Gao X, Borriss R (2015) Novel routes for improving biocontrol activity of Bacillus based bioinoculants. Frontiers in Microbiology 6:1395. https://doi.org/10.3389/fmicb.2015.01395

64. Zhang J, Li Y, Yuan H, Sun B, Li H (2016) Biological control of the cereal cyst nematode (Heterodera filipjevi) by Achromobacter xylosoxidans isolate 09X01 and Bacillus cereus isolate 09B18. Biological Control 92:1-6. https://doi.org/10.1016/j.biocontrol.2015.08.004

65. Zhang Y, Wang Y, Qin Y, Li P (2020) Complete genome sequence of Bacillus velezensis LPL-K103, an antifungal cyclic lipopeptide bacillomycin L producer from the surface of lemon. 3 Biotech 10(1):8. https://doi.org/10.1007/s13205-019-1995-y 
66. Zhu Zheyuan, Peng Qiong, Man Yilong, Li Zuren, Zhou Xiaomao, Bai Lianyang, Peng Di (2020) Analysis of the Antifungal Properties of Bacillus velezensis B-4 Through a Bioassay and CompleteGenome Sequencing. Frontiers in Genetics 11: 703. https://doi.org/10.3389/fgene.2020.00703

67. Zohara F, Akanda AM, Paul NC, Rahman M, Islam T (2015) Inhibitory effects of Pseudomonas spp. on plant pathogen Phytophthora capsiciin vitro and in planta. Biocatalysis and Agricultural Biotechnology 5:69-77. https://doi.org/10.1016/j.bcab.2015.12.00956.

68. Zubrod JP, Bundschuh M, Arts G, Brühl CA, Imfeld G, Knäbel A, Payraudeau S, Rasmussen JJ, Rohr J, Scharmüller A, Smalling K, Stehle S, Schulz R, Schäfer RB (2019) Fungicides: An overlooked pesticide class? Environmental Science \& Technology 53:3347-3365. https://doi.org/10.1021/acs.est.8b04392

\section{Figures}

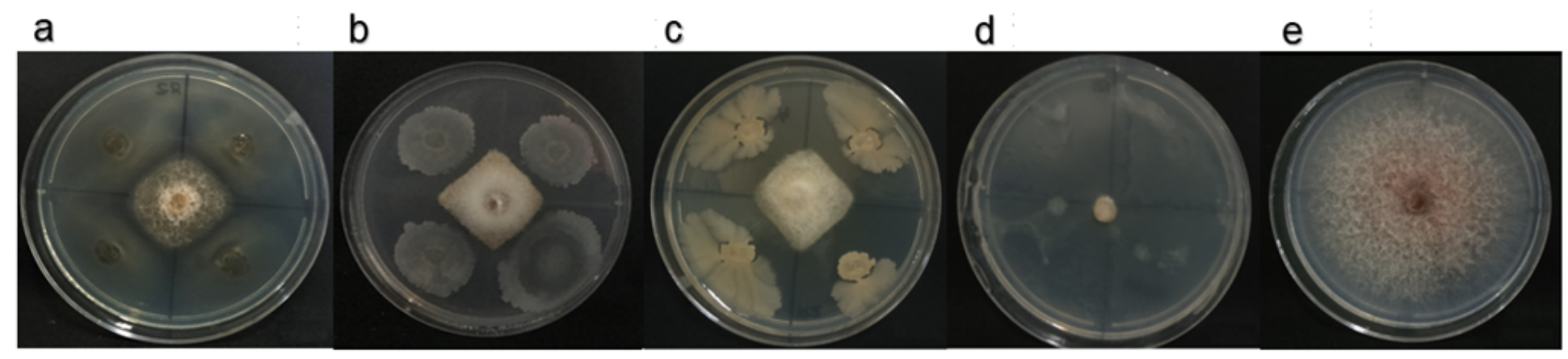

\section{Figure 1}

The in vitro antagonistic activity of four bacterial strains against Fusarium verticillioides. (A) Pseudomonas aeruginosa (IPR45), (B) Bacillus velezensis (CT02), (C) B. velezensis (IM14), and (D) Achromobacter xylosoxidans (ISD04). (E) F. verticillioides used as control. Fusarium verticillioides growth inhibition is evidenced by a clear area around the phytopathogen in the center of the plates, except in (D) 
a

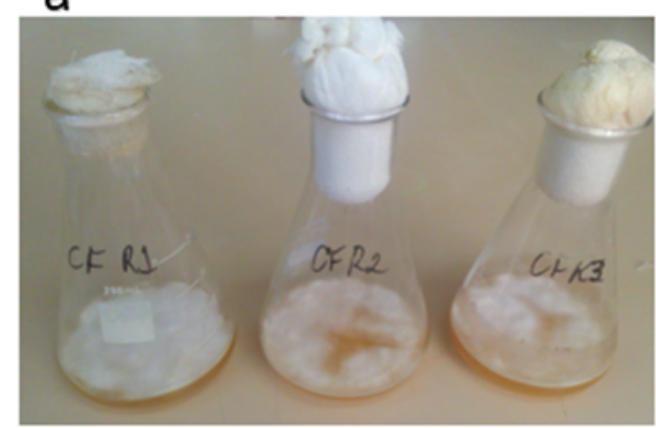

d

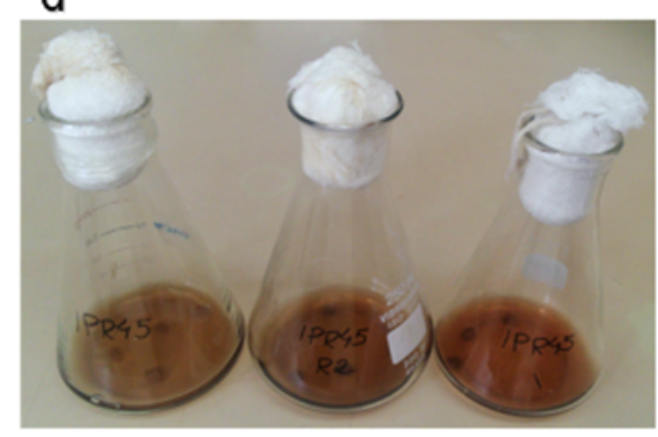

b



e

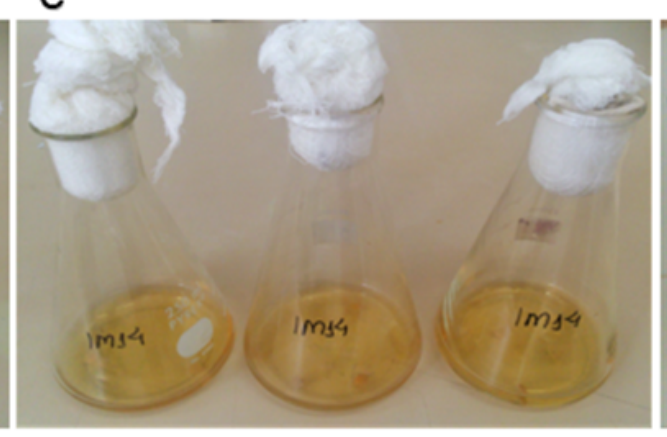

C

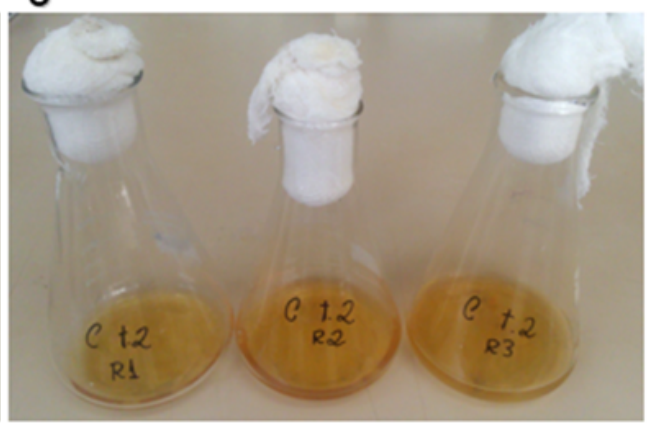
f

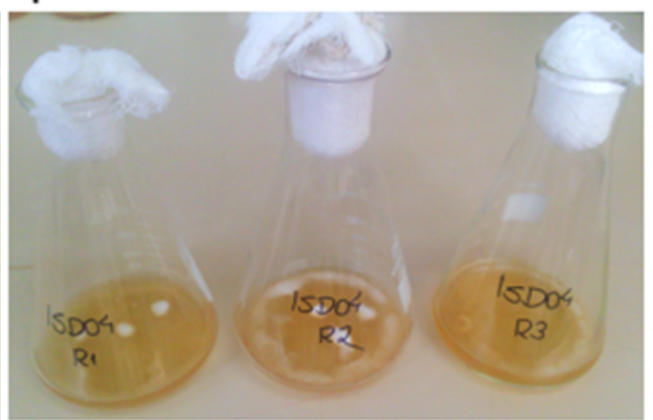

Figure 2

Effects of cell-free bacterial culture supernatants on mycelial growth of Fusarium verticillioides in liquid medium. (A) Control inoculated with F. verticillioides in TSB plus streptomycin, (B) Culture medium without inoculation (control). From (C) to $(F)$, free filtrate of bacterial culture cells inoculated with $F$. verticillioides discs (C) Bacillus velezensis (CT02), (D) Pseudomonas aeruginosa (IPR45), (E) B. velezensis (IM14), and (F) Achromobacter xylosoxidans (ISD04). The white matters inside the flasks correspond to mycelial growth of Fusarium verticillioides. 


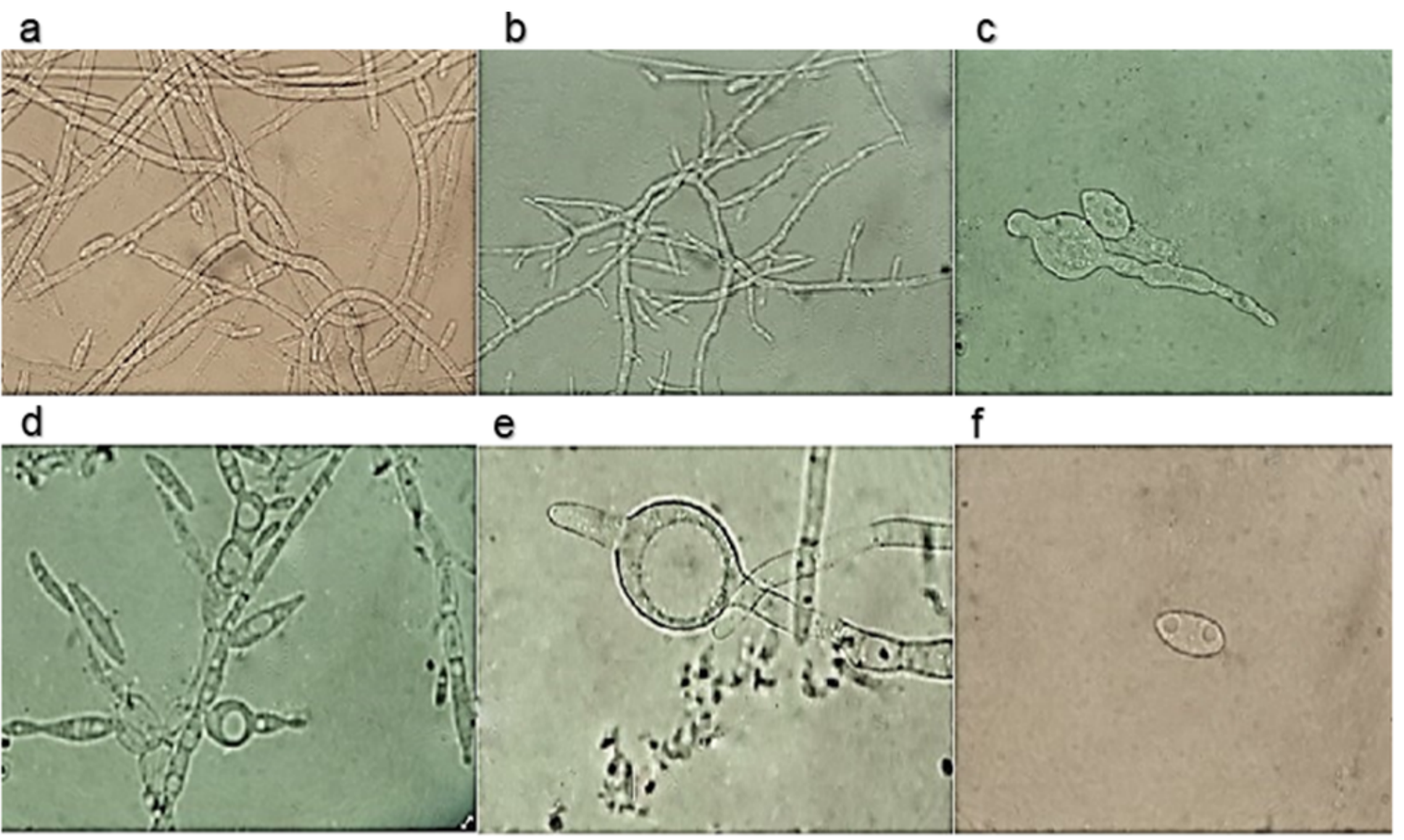

Figure 3

Effect of cell-free filtered culture supernatant on hyphae growth and conidia development. (A) Hyphae growth of Fusarium verticillioides used as the control, (B) Fungal hyphae without abnormalities growing in the presence of cell-free filtrate A. xylosoxidans (isolate ISD04). Morphological abnormalities in the development of fungal conidia in cell-free filtrates of the Bacillus velezensis strains IM14 (C) and CT02 (D and $E$ ). (F) ungerminated conidia of F. verticillioides after $24 \mathrm{~h}$ of incubation in the Pseudomonas aeruginosa cell-free filtrate

a

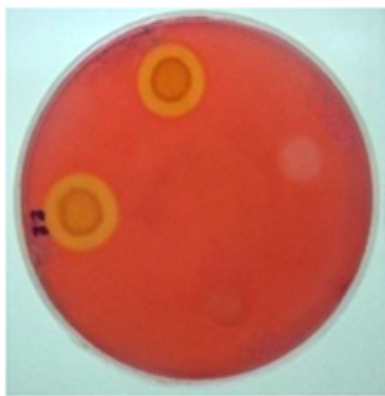

b



C

d



\section{Figure 4}

Enzymatic activity test for the four bacteria isolated from the maize silks. Formation of halos indicative of the production of cellulase (A), pectinase (B), protease (C), lipase (D), and chitinase (E). The four strains were inoculated on the same plate 


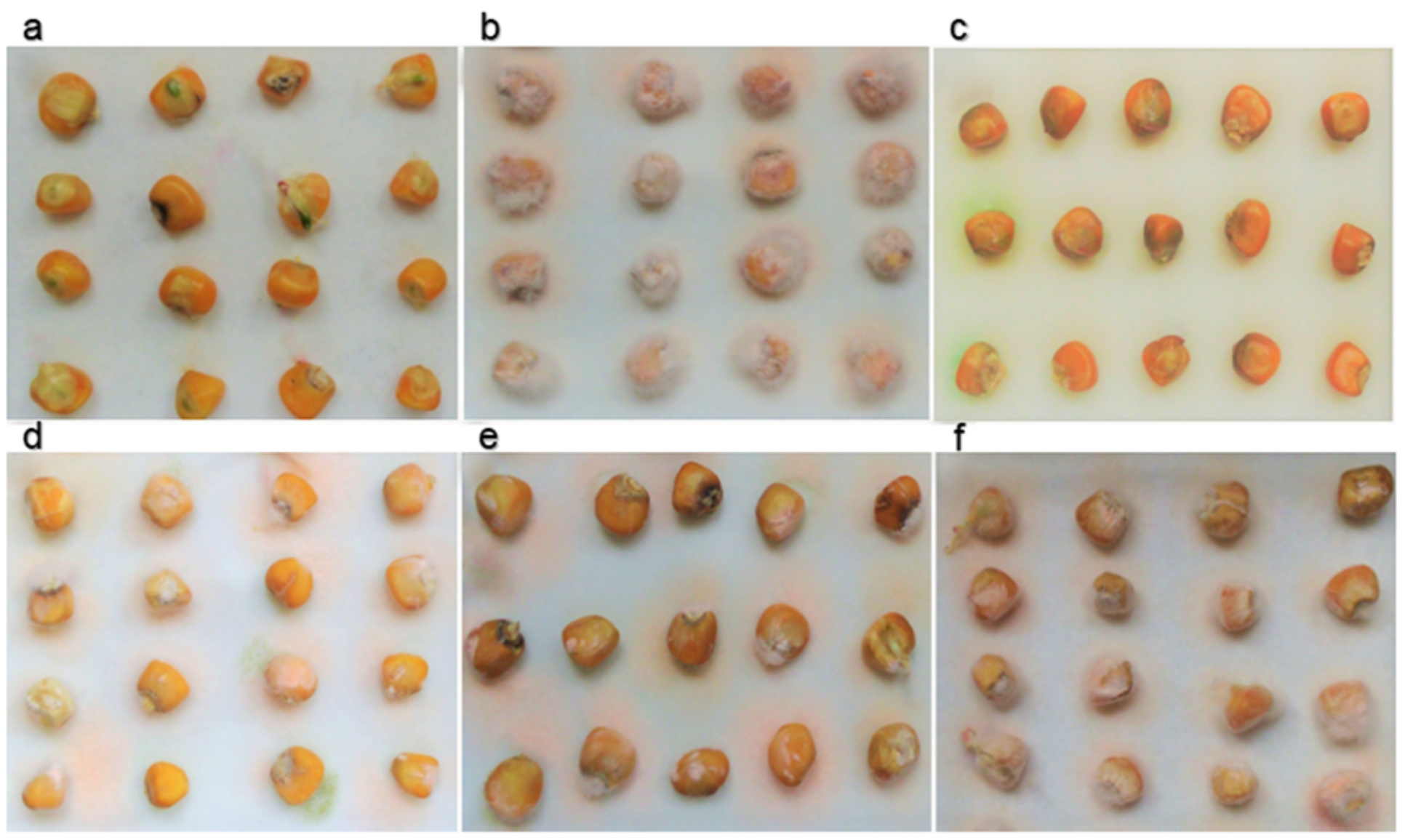

Figure 5

Effects of maize seeds microbiolization on F. verticillioides growth. (A) Absence of fungal growth in disinfected seeds, (B) fungal incidence in seeds inoculated with F. verticillioides, (C) to (F) Seeds microbiolized with Pseudomonas aeruginosa (C), Bacillus velezensis CT02 (D) and IM14 (E), and Achromobacter xylosoxidans ISD04 (F) 


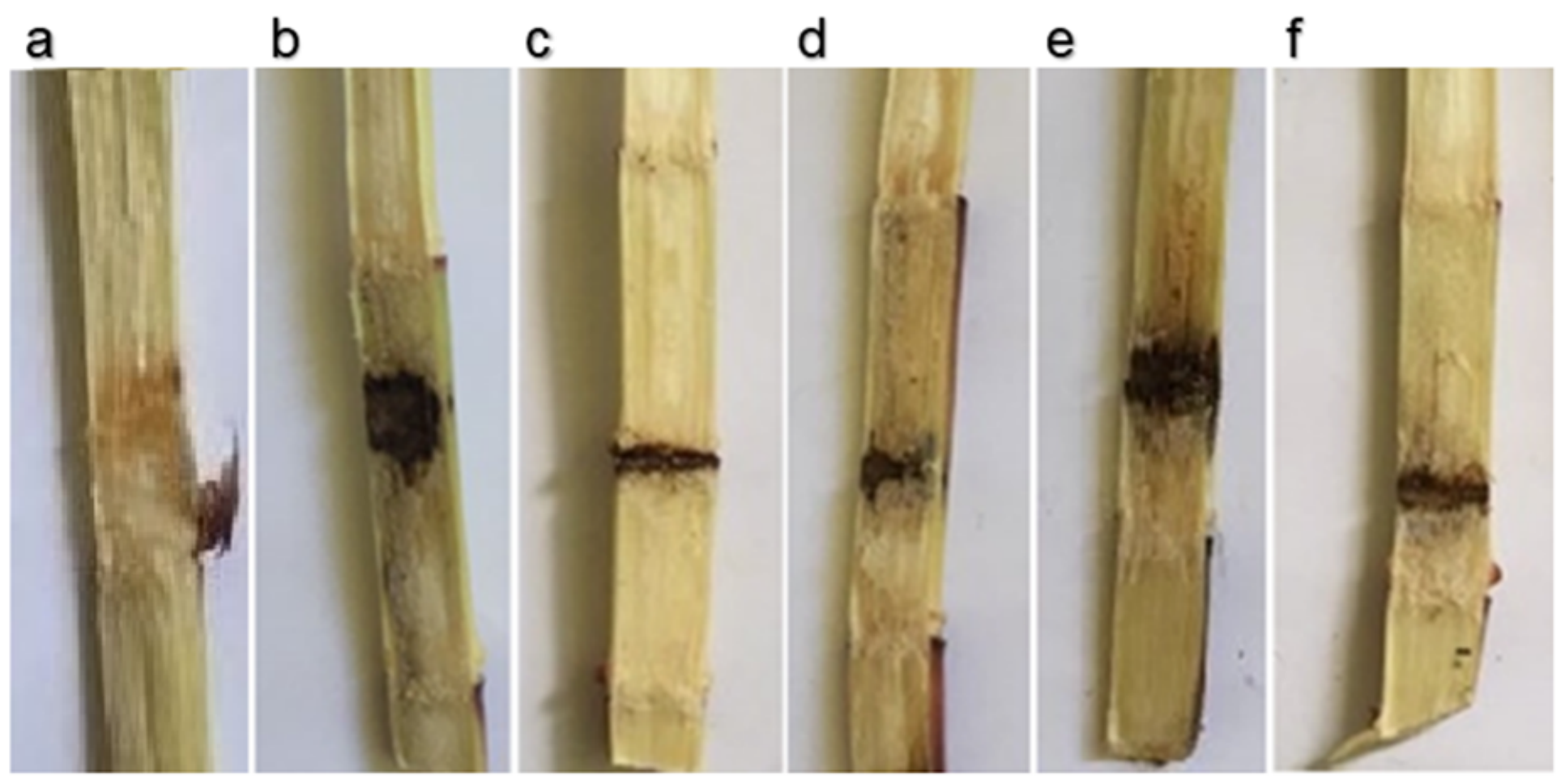

\section{Figure 6}

Effect of seed treatment with four bacterial strains on stalk rot caused by Fusarium verticillioides. (A) non-inoculated control (B) inoculation of $F$. verticillioides in plants originated from non-microbiolized seeds. From (C) to (F), all treatments were inoculated with F. verticillioides (C) Achromobacter xylosoxidans (ISD04), (D) Pseudomonas aeruginosa (IPR45), (E) Bacillus velezensis (IM14), and (F) Bacillus velezensis (CT02) 